\title{
ANALYSIS OF THE PROBLEMS OF EFFECTIVE USE OF LOCAL BUDGET FUNDS AND THEIR CAUSES (in the case of Fergana region)
}

\author{
Ismoilova Sanobarkhon Yakubovna \\ Fergana State University, \\ Uzbekistan
}

Article DOI: https://doi.org/10.36713/epra0327

\begin{abstract}
The article analyzes the problems of effective use of local budget funds and their causes on the example of the Ferghana region.
\end{abstract}

KEYWORDS: local budget, revenues and expenditures, financing, deficit, appropriations, illegal expenditures.

\section{INTRODUCTION}

Every year, a huge amount of money is spent from the state budget of our country in order to ensure its development and increase the welfare of the population. And the main part of them is carried out through local budgets. In turn, a large part of the funds that are being spent through local budgets has a social orientation. Its level, in some years, reaches $95.0-97.0 \%$ on the local budgets taken separately.

In the conditions of a market economy, any funds are subject to its effective spending. This also applies to any expenses incurred from the budget, including the account of local budgets. However, as practice shows, it is still problematic to ensure effective spending of funds, especially within the local budgets. No matter how much effort is being made, managers of local budget funds during their activities allow the illegal use of resources.

\section{LITERATURE REVIEW}

Some aspects of ensuring effective use of state or local budgets funds have been investigated to some extent in the economic (financial) literature. In this direction, scientific work and research carried out by Uzbekistan's economists-scientists and practicing specialists T.S.Malikov, O.A.Olimjanov,
A.K.Iminov, J.A.Kuchkorov, N.H.Haydarov, D.H.Polotov, D.A.Rahmonov, Z.H.Srojiddinova, O.G'.Gaybullaev, U.Orokov, G. Kosimova and others. In particular, the issues of using separately received state budget expenditures as social networks (expenditures for supporting the education system, health care, and social security of the population) were studied by B. I. Nurmukhamedova, and N. Yuldasheva at the level of local budgets, from the point of medium-term budget planning view were learned by Sh. Fayzullayeva and I. A. Azizova.

\section{RESEARCH METHODOLOGY}

During the study, statistical and economic analysis methods such as analysis and synthesis, induction and deduction, abstract-logical analysis and comparison, correlation and regression were used.

\section{ANALYSIS AND RESULTS}

The results of the analysis carried out will allow us to identify the problems and the reasons for their occurrence, including the effective use of local budget funds in Fergana region. Despite this, in our opinion, the approach here should initially be taken from the analysis of the data presented in Table 1. 
Table \#1

The dynamics of changes in revenues and expenditures of the Fergana region budget compared to the previous year and their differences, in \%

\begin{tabular}{|c|c|c|c|c|}
\hline$\#$ & \multirow{2}{*}{ years } & $\begin{array}{c}\text { Changes in income and expenses compared } \\
\text { to the previous year }\end{array}$ & $\begin{array}{c}\text { Cost changes in relation to } \\
\text { revenue } \\
(+,-)\end{array}$ \\
\cline { 3 - 4 } & Incomes in \% & Expenses in \% & - \\
\hline 1. & 2010 & - & - & $-17,42$ \\
\hline 2. & 2011 & $+40,20$ & $+22,78$ & $+13,22$ \\
\hline 3. & 2012 & $+16,27$ & $+29,49$ & $+6,73$ \\
\hline 4. & 2013 & $+16,42$ & $+23,15$ & $-1,0$ \\
\hline 5. & 2014 & $+15,03$ & $+14,03$ & $-0,33$ \\
\hline 6. & 2015 & $+11,59$ & $+11,26$ & $+1,42$ \\
\hline 7. & 2016 & $+5,89$ & $+7,31$ & $-14,53$ \\
\hline 8. & 2017 & $+18,58$ & $+4,05$ & $+34,42$ \\
\hline 9. & 2018 & $+12,00$ & $+46,42$ & $-237,22$ \\
\hline 10. & 2019 & $+286,7$ & $+49,48$ & \\
\hline
\end{tabular}

Source: It was compiled by the author on the basis of data from the financial Department of Fergana Region.

As can be seen from Table 1, it shows the growth rates of revenues and expenditures of the budget of Fergana region for 2010-2019 years compared to the previous year. According to it, during these years the revenues of the budget of the Ferghana region have the character of growing steadily and their growth rate from 5.89\% (2016 year) to $286.7 \%(! ! !)(2019$ year). In addition, the growth rate of the budget revenues of the Ferghana region is characterized by the fluctuation as a whole. Of course, this thing generates certain difficulties or problems in the implementation (financing)of costs from the same budget. Also, such fluctuation does not remain without its negative impact on the efficiency of the costs incurred from the budget of the Ferghana region. At the same time, the budget expenditures of Fergana region have also increased year-by-year during this period. These growth rates ranged from 4,05\% (2017 year) to 49,48\% (2019 year). For year-by-year costs growth rates are also typically fluctuated. It is clear that this also raises certain problems in ensuring their effective spending. One of the most important conclusions that can be drawn on the basis of Table 1 data, in our opinion, is that there is no correlation between the year-by-year growth rates of revenues and expenditures of the budget of the Fergana Region. In our opinion, in this matter, of course, there must be balance between them. This means that the expenditure of local budgets should also be increased in accordance with their income. However, Table 1 data shows that in the budget of the Fergana region, we can see that not all the time in the practical rule, which does not require proof of this, is also not adhered to. In practice, costs, especially at the level of local budgets, can go far beyond the limit of revenues within these budgets. There are various reasons for this, which are mainly due to the fact that the same district or region is subject to the level or pace of socio-economic development. In such cases, the excess of expenses can usually be covered or financed from a higher budget (for example, from the budget of the Republic) on the account of the allocation of appropriate funds in different views. In our opinion, such a situation in Fergana Region for 2010-2019 may have occurred in 2012-2013, 2016 and 2018 and in this case it is possible to be financed from the account of high (Republican) budget funds, including the High (Republican) budget expenditures at a higher rate than the revenues of the regional budget. While analyzing the data of Table 1, it is worth paying attention to one more case. In this place, the analysis of the growth rates of revenues of the Fergana region budget for 2010-2019 years, the growth rates of the same budget expenditures go on about 5 times high. The fact is that the above table data showed that such a situation occurred in 2014, 2015, 2017 and 2019. This, of course, can be caused by some kind of objects. But, in our opinion, at a time when the budget revenues increased by $40,2 \%$, its expenditures increased by $22,78 \%$ (in 2011 year) or $18,58 \%$ of the budget revenues, despite the fact that during this period, its expenditures increased by $4,05 \%$ (in 2017 year) and finally, an increase of $286,7 \%$ of budget revenues to $49,48 \%$ of the costs associated with it during the same period needs an explanation, and all of the above indicates the presence of certain problems here. According to our reckoning, these problems can also be explained by the opportunities that have been dispensed with in the planning of the revenues and expenses of the budget of the Fergana region for these years. In the absence of such a situation, in our opinion, the transition from annual planning of local budgets to medium-term planning plays a special role. Now let's try to look at this problem even lower, that is, at the intersection of districts. As an example, we will use data from the Kushtepa District of Fergana region. Therefore, the 
following table 2 presents the dynamics of changes in revenues and expenditures of the budget of the
Kushtepa District of Fergana region of the Republic of Uzbekistan and the differences between them.

Table\#2

The dynamics of changes in income and expenses of the budget of the Kushtepa District of Fergana region, Uzbekistan compared to the previous year and differences between them, in \%

\begin{tabular}{|c|c|c|c|c|}
\hline \multirow{2}{*}{$\#$} & \multirow{2}{*}{ Years } & Revenue changes & Expenses changes & $\begin{array}{c}\text { Difference of changes in income } \\
\text { and expenses (+, -) }\end{array}$ \\
\cline { 3 - 5 } & & - & - & - \\
\hline 1. & 2010 & 26,72 & 22,91 & $-3,81$ \\
\hline 2. & 2011 & 26,22 & 25,80 & $-0,42$ \\
\hline 3. & 2012 & 13,75 & 12,94 & $-0,81$ \\
\hline 4. & 2013 & 43,41 & 39,89 & $-3,52$ \\
\hline 5. & 2014 & 23,29 & 9,59 & $-13,70$ \\
\hline 6. & 2015 & 8,37 & 7,92 & $-0,45$ \\
\hline 7. & 2016 & 16,14 & 6,28 & $-9,86$ \\
\hline 8. & 2017 & 56,57 & 37,02 & $-19,55$ \\
\hline 9. & 2018 & 970,02 & 160,32 & $-809,70$ \\
\hline 10. & 2019 & & & \\
\hline
\end{tabular}

This means that the data presented in Table 2 shows that the problem with the change in revenue and expenditure of local budgets from year to year and the dynamics of the differences between them has taken more acute tone at the district level than at the regional level.

So, if 5 of the previous table\#1 data has a sign (-) (the growth rate of budget expenditures is lower than that of revenues) and $4(+)$ has a sign (on the contrary, the growth rate of budget expenditures is higher than that of its earnings), then, as can be seen from the table\#2 data, all of them have a $\operatorname{sign}(-)$, that is, in all the years under analysis, the growth rate of costs was at a level lower than its earnings. This, on the one hand, can be positively assessed, that is, the expenditure of the Koshtepa district budget was carried out within the framework of its income, there were no excessive expenditures, etc. However, this can be assessed, on the second hand, negatively, that is, in the Kushtepa district, even within the framework of the existing income, costs have not been realized. Because at a time when social problems that need to be solved at the crossroads of districts are becoming increasingly acute, it is much more difficult to explain this, that is, extreme austerity in some years (for example, in 2018 and 2019 years). Speaking about the problems of effective use of local budget funds and the reasons for their occurrence, it is worthwhile to touch on another problem that has long been included in the practice not only in the Fergana region, but also in the whole Republic and is still coming without a solution and the reason for its origin. The question is about the deficit, appropriation and illegal expenditure, which is firmly deep-rooted in the practice of our country and consists not only in relation to the local budget costs, but also in relation to the state budget costs in general. This is exactly the case with the budget of the Fergana region, the results of our research carried out on the example above once again confirmed. Therefore, it is of key importance to recognize this as one of the most fundamental problems that hinders the effective expenditure of the budget, including local budgets, and to identify the reasons for its occurrence. Indeed, as the results of our analysis carried out above show, the deficit, which is a component of the budget expenditure, the appropriation and illegal expenditure, in our practice, occurs steadily every year and is repeated from year to year. Although their scale in each region is equal to several tens of billion soums, on the country's scale, this amount reaches several hundreds of billion soums. Despite the fact that a certain part of them is being restored to the budget as a result of the implementation of various activities, it is not possible to restore another part at all. For example, according to the data of Table 1, It was impossible to restore funds to the budget in Fergana region in $2010-8.0 \%$, in $2014-21.3 \%$, in $2015-12.1 \%$, in $2016-8.5 \%$, in $2017-22.3 \%$, in $2018-20.4 \%$ and in $2019-9.9 \%$. So, as can be seen from this, in 3 of the 7 cases, the deficit committed from the account of budgetary funds, from every 5 sums of appropriation and illegal expenses, 1 sum was not returned to the budget (not restored). There are at least a few reasons why both of the above situations (on the one hand, the deficit, the appropriation and the fact that illegal expenditures are committed repeatedly every year, and on the other hand, they are not completely re-established in the budget) occur continuously from year to year. Firstly, the sense and responsibility of ensuring that 
these funds are effectively spent in budgetary allocators has not been fully formed. They have an indifferent (unfamiliar) mood about the fact that these funds are their own funds. They do not fully feel responsibility and obligation in this direction. Secondly, in practice, even in users of budgetary funds, the same mood was formed as above. In our opinion, the solution to the problem of ensuring the effective use of budget (including local budget) funds, will remain complicated, if the situation is not changed, first of all, even in the case of both of the above. World practice shows that this problem is impossible without a sharp increase in the responsibility and obligation of both sides in this direction.

\section{SUMMARY AND SUGGESTIONS}

Taking into account the above, in our opinion, it is worth paying attention to the following:

1. To achieve a $100.0 \%$ recovery in a relatively short period of the above funds from the accounts of all the perpetrators who have committed a deficit in relation to budgetary funds, including local budgetary funds, assimilating them and preventing the occurrence of illegal expenditures. Also, it is important not to take into account any object or sub-causes and to take them into account at the time of making the appropriate decision;

2. Refusal to apply the concept or indicator of "funds that have not been restored to the budget" in practice. Instead, if it is not possible for the deficit, appropriation and illegal expenditure to be returned to the budget during the relevant period, it is necessary to formalize them as a "loan", which should be collected in relation to the relevant subjects, and also provide for the additional payment of the corresponding interest in this. In our opinion, there is nothing surprising or unusual in this. Because the budget, including the funds that have not been recovered within the time limit set for the disposal of the local budgets, nevertheless, means the use of funds that do not belong to them at the disposal of someone or by someone. It does not differ from the loan given in its economic essence. Therefore, it must be returned all the same and also pay the fee for its use. On top of this, the introduction of the above order into practice also does not contradict the market mechanism;

3. It is difficult to believe that the deficit, appropriation and illegal expenditure of a part of the budget and local budget expenditures, including those, occurs without the participation of "budget allocators" in our opinion. On the contrary, if this process is in the constant focus of the same "budget allocators", monitoring is carried out by them on the continuous use of these funds, in our opinion, there is no possibility of reducing the deficit, appropriation and illegal expenditure to a minimum and equating it to zero. Therefore, it is worthwhile to reconsider, in our view, the issues related to both responsibility and obligation of such subjects, taking into account their contribution in the occurrence of deficit, appropriation and illegal expenditure in relation to budgetary expenditures. For example, "allocators of budgetary funds" should be additionally encouraged if they did not allow for the occurrence of a deficit, appropriation and illegal expenditure on budgetary expenditures during their annual activities, and, conversely, should be punished from a material (financial) point of view. The introduction of such a procedure, in our opinion, would be in line with the nowadays spirit and the state policy currently being implemented in Uzbekistan.

4. We believe that it is also necessary to dwell on the problems of the effective use of local budget funds and the reasons for their occurrence at the local level when an opinion is being made about the extent to which budgetary expenditures are planned at the local level. Based on the results of the analysis carried out, it can be said that, including the actual circumstances that exist when the expenditure of local budgets is planned, are not taken into account in sufficient quantity. For example, we are witnessing that even the level of revenues and their growth rates from year to year have remained, to a certain extent, inattentive, when the overall plan of expenditure is being drawn up in local budgets (see Table 1 and 2 figures). In practice, there are also cases when this is the opposite, that is, within the local budget, expenses are planned in such a way that they exceed its income (see Table 1).

In this regard, we should emphasize that the level of year-round growth rates of revenues and expenditures in the budgets of Fergana region and one of its districts during the 2010-2019 years being analyzed, especially in the Kushtepa district, is also one of the problems that is not sufficiently justified by the plans drawn up in this direction. As can be seen from the above-mentioned tables, if the growth rate of revenues in a year amounted to $40,2 \%$ (compared to 2010 in 2011) compared to the previous year, the rate of this indicator in the next year was $16.27 \%$ (compared to 2011 in 2012). The same opinion can be expressed about costs. For example, if the expenditure of the budget of Fergana region in 2017 year increased by 4,05\% compared to 2016 year, the rate of this indicator for 2018 year was $46,42 \%$ compared to 2017 year, that is, the growth rate was 10,0 times higher than in the previous year, etc. The same can be said about the fact that the case is included in practice in the section of the Kushtepa District of the Fergana Region.

All of the above is evident in the issue of revenue and expenditure planning within the framework of local budgets, in many cases, since there is a non - violent approach, they, in the end, will not have its negative impact on the issue of 
ensuring effective spending of local budgets funds. As one of the reasons for this, in our opinion, we can show that the relevant experts are preventing some kind of neglect in the budgetary process.

\section{LITERATURE REVIEW}

1. President Decree of the Republic of Uzbekistan of Mirziyoyev № PF-5283 "On additional measures related to improvement responsibility of tax and financial authorities for increasing financial freedom of local government bodies, ensuring the completeness of receipts to local budgets" on 13 December 2017.

2. Malikov T. Olimjonov O. Finance. Textbook. - T.: "Iqtisod-moliya", 2019. - 800 p.

3. Malikov T.C., Haydarov N. H. Budget income and expenses. Textbook. - T.: "Iqtisod-moliya", 2007.$245 p$.

4. Malikov T.C., Haydarov N. H. State budget. Textbook. - T.: "Iqtisod-moliya", 2008.-112p.

5. Vahobov A. V. Malikov T.S. Finance. Textbook. - T.: "Noshir", 2012. - 712 p.

6. Pulatov D. H., Nurmuhammedova B.I. Treasury. Textbook. - T.: "Sano-standart", 2014. - 2726.

7. Nurmuhammedova B.I. State budget. Workbook. "Iqtisod-moliya", 2018.

8. Nurmuhamedova B.I. Srojiddinova Z.X., Sugirbayev G.G. Planning education cost in Uzbekistan. T.: "InfoCapitalGrup", 2013. - 447 p.

9. Yuldasheva N.B. Local budget. - T.: "Iqtisodmoliya", 2015. - $362 \mathrm{c}$.

10. Ismoilova S. HOW TO USE LOCAL BUDGET? //International Finance and Accounting. - 2020. - T.

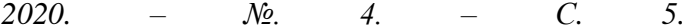
https://uzjournals.edu.uz/interfinance/vol2020/iss4/5? utm_source $=$ uzjournals.edu.uz\%2Finterfinance $\% 2 F v$ ol2020\%2Fiss 4\%2F5\&utm_medium=PDF\&utm_cam paign $=$ PDFCoverPages

11. Ismoilova, S. Y. (2019). Fiscal advantages and disadvantages of local government. Образование $u$ наука в России и за рубежом, (16), 165-170.

https://www.google.com/search?rlz=1C1GCEA enU Z812UZ812\&sxsrf =ALeKk01Q9enqYt8CCWgsHRpd CyRXgDZtmw:1608932767315\&q=Ismoilova, + S. + Y. $+(2019) .+$ Fiscal + advantages + and + disadvantages $+O$ f+local + government. $\%$ D0\%9E\%D0\%B1\%D1\%80 \%D0\%B0\%D0\%B7\%D0\%BE\%D0\%B2\%D0\%B0\%D O\%BD\%D0\%B8\%D0\%B5+\%D0\%B8+\%D0\%BD\%D $\underline{0 \% B 0 \% D 1 \% 83 \% D 0 \% B A \% D 0 \% B}$ 